Vol. 19 No. 1, 2021
ISSN (online): 2746-4652
doi: 1 https://doi.org/10.33369/jwacana.v19i1.6578

\title{
ANALYSIS OF CONFLICT IN A MISFORTUNE BY ANTON CHEKHOV
}

\author{
Dwi Uswatun Khasanah
}

University of Muhammadiyah Bengkulu

Email: uswatunkhasanah.dwi@gmail.com

\begin{abstract}
This paper aims to find the conflict that exists in the story of A Misfortune by Anton Chekhov. This research method is descriptive analytical research methods. The data collection technique of this study uses documentary techniques sourced from the stories of A Misfortune by Anton Chekhov. The conflict found by researchers in the form of sentences, phrases and word quotations. Based on the analysis carried out, the researchers also found two types of conflicts, namely people vs. self and people vs. people. The first, the main character who has a conflict with himself such as feelings of doubt, confusion, anger, chaos, sadness, despair, shock, fear, regret, revenge, and annoyance. Second, the main character has problem with other character figures such as quarrels, debates, disagreements, and disputes.
\end{abstract}

Keyword: conflict, type conflict

\begin{abstract}
Abstrak
Tulisan ini bertujuan untuk menemukan konflik yang ada dalam cerita A Misfortune karya Anton Chekhov. Metode penelitian ini adalah metode penelitian deskriptif-analitis. Teknik pengumpulan data penelitian ini menggunakan teknik dokumenter yang bersumber dari cerita A Misfortune karya Anton Chekhov. Konflik yang ditemukan peneliti berupa kalimat, frasa dan kutipan kata. Berdasarkan analisis yang dilakukan, peneliti juga menemukan dua jenis konflik yaitu people vs self dan people vs people. Pertama, tokoh utama memiliki konflik dengan dirinya sendiri seperti perasaan ragu, bingung, marah, kacau, sedih, putus asa, kaget, takut, menyesal, dendam, dan jengkel. Kedua, tokoh utama memiliki masalah dengan tokoh tokoh lain seperti pertengkaran, perdebatan, perbedaan pendapat, dan perselisihan.
\end{abstract}

Kata Kunci: konflik, jenis konflik

\section{INTRODUCTION}

Conflict is a problem that will happen to everyone and many people don't want this to happen in their lives. The conflict presented by a writer can't be separated from the fact that its existence is part of human life. Many writers are inspired by conflicts that exist in human life so that the conflict is expressed in an interesting story. Conflicts in short stories are interesting to study because, first, conflict is one of the building blocks of literary works relating to characters, lines, and arrangements that are part of the intrinsic elements in literary works. Second, every time in literature there is always conflict that makes short stories more interesting with problems that arise. Third, in terms of literary work it cannot be known.

The conflict is divided into two, namely, internal conflict and external conflict. Internal conflict is a conflict that occurs within the soul or can be said to be a conflict in one's own feelings. External conflict is a conflict that occurs in the main character with another party, maybe someone else, maybe with the community like debates, disputes, or fights. External conflicts can be divided into two categories, namely physical conflict and social conflict. Physical conflict is a conflict caused 
by a clash between a character and the natural environment such as feelings of revenge. Whereas social conflict is as a social process between two parties or more when one party tries to get rid of the other party by destroying or making it lose.

Short story $A$ Misfortune by Anton Chekhov. The conflict in the story came from a 25-yearold housewife who had a child. This woman who still puts great feelings on her old friend and but asks a friend to stop pursuing his love and remaining like an ordinary friend, because his love for her husband and his respect for "the sanctity of marriage" ensure that nothing will come from his desire, but this woman's attempt to convince him to leave her is futile because of the man the man was always fascinated with him and finally this woman chose with the other man.

Conflict is a problem that is experienced by humans and actually undesirable because it can harm itself. This is in accordance with the opinion, Wall (1985) stated, conflict is a process in which two or more parties attempt to frustrate the other's goal attainment the factors underlying the conflict is divided into three: interdependence, differences in goals, and differences in perception. Wellek and Warren (1995: 285), also stated conflict is something dramatic, referring to a fight between two balanced forces, implying action and retaliation for action.

Based on a number of expert opinions, the researcher concluded that conflict is a problem, a dispute, and a conflict in a story. Conflicts that occur can involve yourself, one character with other characters, leaders with their communities, and leaders with their environment.

Short stories have a definite conflict so that the story will attract the reader's attention to read it. Conflict is a problem that exists in every human being, such as, disputes, conflicts, and disputes are not expected by everyone. Some experts expressed their opinions on conflict. Pruitt and Rubin (1986), put forward that conflict means perceived divergence of interest, or a belief that the parties' current aspirations cannot be achieved simultaneously. The definition of conflict according to Taquiri in Newstorm and Davis (1997) is the inheritance of social life that may apply in various circumstances as a result of the arising of a state of disagreement, controversy and conflict between two parties or more parties in a continuous manner.

Folger, Poole, and Stutman (1997), also stated conflict is the interaction of interdependent people who perceive incompatible goals and interference from each other in achieving those goals. The opinion of other experts Max Weber (1968), social relation is referred to as conflict if insofar as the actions in it intentionally intended to carry out the will of one party against the other. Thus, conflict is a social relationship that is interpreted as the desire to impose its will on the other party.

The conflict is divided into two, namely, internal conflict and external conflict. Internal conflict is a conflict that occurs within the soul or can be said to be a conflict in one's own feelings. Conflicts can be felt, known by oneself or with opponents, expressed through communication behavior (Folger \& Poole: 1984).

External conflict is a conflict that occurs in the main character with another party, maybe someone else, maybe with the community like debates, disputes, or fights. According to Minnery (1985), social conflict is an interaction between two or more parties that are mutually related and interdependent, but separated by differences in goals. Basically, conflict in fiction is generally codified as humans against humans, humans against nature, and humans against themselves.

Conflict consists of several types (Mark Nichol), namely the first person vs. self, this type of conflict occurs when someone who is controlling his emotions in his mind and often involves himself making decisions between right and wrong, or other mixed emotions. The second is people vs. people, this conflict is probably the most common, there is a dispute between two people who want one goal but one of them prevents their opponents from getting what they want. The third person vs. society, this conflict usually occurs in the government, cultural customs or social norms that exist. The fourth person vs. nature, humans are struggling against nature to survive. The fifth person vs. fate/God, this conflict occurs in every human being to struggle to face opposition and cannot avoid from fate. The sixth person vs. supernatural, this conflict occurs in humans who fight things that are not fully known or cannot be understood. And the last, people vs. technology, the world of technology has become very rapid because this conflict affects one or a group of people struggling to overcome technology and be more sophisticated.

The types of story conflicts by Anton Chekhov are of two types, namely individual versus individual and individual versus self. Individual versus individual can be the most common form of external conflict, and also known as interpersonal conflict. This mode lies in the subject of all dramas and places a direct struggle between the protagonist and antagonist or is known as a good person and a villain. The researcher found that the conflict in this story had two parts, the first was the conflict 
between Sofya and Ilyn who had a special relationship without the knowledge of Sofya's husband. And the second happened between Sofya and Andrey (her husband), the destruction of their household with the arrival of a young man who wanted to live with Sofya.

And then Individual versus self is the only true version of internal conflict that you will find in the literature. In this mode, conflicts occur in characters playing characters, and often involve characters between right and wrong, or other mixed emotions. In this story Sofya experienced the conflict because she felt guilty about what she had done before, so it made her heart hesitant to choose a tough decision in her household.

\section{METHOD}

The method used is descriptive method. Descriptive method is data that is analyzed through observation, taking notes, describing and clarifying phenomena. The meaning of the phenomenon here is the conflicts that exist in the story. According to Fraenkel and Wallen (1993), descriptive methods are methods used to explain, analyze and classify things through various techniques, surveys, interviews, questionnaires, observations, and texts. Whintney (1960) also states the descriptive method is a fact-finding process with the right interpretation.

The form of research used in this study is qualitative research, namely research that is intended to observe objects that are studied naturally and the researcher concludes from the data obtained. According to Strauss and Corbin: 1990 (in Hoepfl: 1997 and Golafshani: 2003), qualitative research is a type of research whose findings are not obtained through quantification procedures, statistical calculations, or other means using numerical measures. and Creswell (2002), also stated that the form of data used is not in the form of numbers, numbers, scores or values; rank or frequency; which are usually analyzed using mathematical or statistical calculation.

Qualitative descriptive research is one of the types of research included in this type of qualitative research. The purpose of this study is to reveal events or facts, circumstances, phenomena, variables and circumstances that occur when the study takes place by presenting what actually happened. The purpose of doing this research is not only to explain thoroughly the conflict that will be examined and observed, but also other purposes. The purpose of qualitative descriptive research will be a guideline for us when conducting a study.

Data collection techniques used by researchers to analyze are documentation studies. Documentation study here is the acquisition of data by analyzing the short story and collecting related data. The data source in this study is in the form of text in the form of stories A Misfortune by Anton Chekhov's work which was first published in Novoye Vremya in 1986. The data in this study are internal conflicts and external conflicts in the form of words, phrases, clauses, quotes, sentences, paragraphs, and discourses contained in the story $A$ Misfortune by Anton Chekhov.

\section{FINDING AND DISCUSSION}

The main character in the story of A Misfortune is Sofya who dominates the story from the beginning and end of the story. While the other characters are Ilyn (Sofya's old friend), Andrey (Sofya's husband), Varya (Sofya's son). The researchers' first discussion was to find out internal conflicts with the main characters.

The following is a description of these conflicts. Feelings of chaos, hesitation and regret are psychological conditions and inconveniences about everything that lives. Feelings of chaos, doubt and regret are always felt by every human being, these feelings are caused by involvement, disputes, and quarrels with friends even with their own family members. This feeling was felt by Sofya whose love was always pursued by a young man who had become his old friend. Sofya accepts doubt, confusion and regret for having to choose an old friend or family.

There is a debate between Sofya and Ilyn, can be seen from the following quote. And now I am glad we have met. I want to speak to you seriously and once for all. (A Misfortune, 1986:p.1).

Every human being wants to have a harmonious, peaceful and always shared household until old age. As in this story, damaged households are caused by the arrival of another young man who wants the love of a woman who has a husband and a child. Sofya, who was chased by another man, was an old friend who tried to arouse Sofya's heart to return to the young man.

"You ought to realize that it's not a very nice part you are playing. I am married; I love and respect my husband ... I have a daughter ... Can you think all that means nothing. Besides, as an old friend you know my attitude to family life and my view of the sanctity of marriage."(A Misfortune, 1986:p.1). 
The quote depicts Sofya who feels uncomfortable with what Ilyn did. He asserted and continued to convince Ilyn to realize that Ilyn's pursued love had been taken care of by other people who were more entitled and Sofya already had children from her husband. With this quote, can you think that all that means nothing? Stating that everything Ilyn did to get Sofya would be in vain would not result in results.

Quoting the following states that Sofya wanted to tell his story with the young man.

Yes yes.. I love my husband, I respect him; and in any case I value the peace of my home. I would rather let myself be killed than be cause of unhappiness to Andrey and his daughter ... And I beg you, Ivan Mihalovitch for God's sake, leave me in peace! Let us be as good, true friends as we used to be, and give up these sighs and groans, which really don't suit you. It's settled and it's over! Not a word about it. Let us talk of something else." (A Misfortune, 1986:p.1).

Guilt is a form of emotion that cannot be avoided and often occurs in everyday life. Both large and small, everyone must have felt guilty. Sofya starts feeling guilty when she returns after meeting Ilyn. "You low creature!" she said, upbraiding herself. "You low creature!" (A Misfortune, 1986: p.5).

In the following quote illustrates Sofya felt guilty and murmured blaming himself for what she had done without the knowledge of Andrey and his daughter.

"Poor Andrey!" she said to herself, trying as she thought of her husband to put into her face as tender an expression as she could. "Varya, my poor little girl, doesn't know what a mother she has! Forgive me, my dear ones! I love you so much ... so much!" (A Misfortune, 1986: p.5).

Hate is an emotion that is very strong and symbolizes dislike, hostility, or antipathy for someone, a thing, an item, or a phenomenon. This is also a desire to avoid, destroy or eliminate it. After Sofya calmed down, he saw Andrey who had just returned from work and hardly greeted Andrey. A false feeling began to appear in Sofya's heart so that it became a feeling of hatred towards Andrey. "My goodness!" thought Sofya Petrovna. "I love and respect him, but ... why does he munch so repulsively?" (A Misfortune, 1986:p.6).

The following is the conflict that exists in Sofya who is through her feelings. And why did I go there this afternoon like a fool.?" she thought, tormenting herself. "And am I really so weak that I cannot depend upon myself?" (A Misfortune, 1986:p.6).

In the quote, Sofya loves and respects Andrey as her husband, but Sofya's thoughts and feelings are a little hateful towards her own husband because he still remembers clearly the problem with Ilyn. "It seems as though there is something going wrong with me," she thought from time to time through her laughter and singing." (A Misfortune, 1986:p.8).

The following is a quote that states Sofya and Ilyn are arguing with a love dispute between them. "If not today, then tomorrow you will have to give in! Why, then, this waste of time? My precious, darling Sofya, the sentence is passed; why put off the execution? Why deceive yourself?" (A Misfortune, 1986:p.8).

The following quote states that the conflict Sofya felt guilty and felt herself inferior. "Immoral wretch! Low creature!" she nagged at herself for her weakness. "So that's what your're like!" (A Misfortune, 1986:p.9).

The following quote is the conflict between Sofya and Andrey, when Sofya wanted to invite her husband to go to another city, but the husband refused to go.

"If I am to go, it's time," thought Sofya Petrovna. Her heart suddenly began beating violently.

"Andrey!" she almost shrieked. "Listen! we . . we are going.? Yes?"

"Yes, I've told you already: you go alone."

"But listen," she began. "If you don't go with me, you are in danger of losing me. I believe I am ... in love already."

"With whom?" asked Andrey Ilyitch.

"It can't make any difference to you who it is!" cried Sofya Petrovna. (A

Misfortune, 1986:p.10).

\section{CONCLUSION}


Conflict is motivated by differences in the characteristics that individuals carry in an interaction. These differences include the physical characteristics, intelligence, knowledge, customs, beliefs, and so forth. By bringing together individual characteristics in social interaction, conflict is a natural situation in every society and not even one community has never experienced conflict between its members or with other community groups, conflicts will only disappear along with the disappearance of the community itself.

Based on data analysis of conflict on the story of Anton Chekhov's misfortune. Sofya's internal conflicts include: feeling guilty, confused, scared, indecisive, angry, sad, and desperate. External conflict on Sofya in the story of Anton Chekhov's misfortune which covers social conflict. External conflicts experienced by Sofya with other figures such as Ilyn, and Andrey, included arguments, debates and disputes.

\section{REFERENCES}

Bell,James Scott. Elements of Fiction Writing-Conflict and Suspense. California: F+W Media, 2012. Google book. Web. 20 Dec. 2018.

Bordone, Robert C., and Nido Sara E. del. The Negotiation Within: The Impact of Internal Conflict Over Identity and Role on Across-The-Table Negotiation. University of Missouri School of Law Scholarship Repository. 2014. Print.

Evans, Brad. Types of Conflict-Four Classifications. 2013.

Chekhov, Anton. A Misfortune. Trans. Constance Garnett. In Anton Chekhov: The Collected Novellas and Sort Stories. e-artnow. 2015. Print.

Elizabeth Irvin Ross. Write Now. Barnes \& Noble Publishing. p. 108. 1993. Print.

Ingermanson, Randy, and Peter Economy. Writing Fiction for Dummies. Canada: Wiley Publishing, 2010. Google book. Web. 20 Dec. 2018.

Johnson, Ronald L. Anton Chekhov: A Study of the Short Fiction. New York: Twayne. 1993. Print.

Loehlin, James N. The Cambridge Introduction to Chekhov, p. 51. Cambridge University Press. 2010. Print.

Nichol, Mark. 7 Types of Narrative Conflict. 2013.

Ramer, Samuel C. Conflict, Social Identity, and Violence in the World of Russian Rural Medicine: Two Chekhov Stories. USA: Tulane University. 2015. Print.

Schwarz, Oliver. Conflict - A Literature Review. Essen: University of Duisburg: 2006. Print.

Simpon, Judith. Foundations of Fiction. iUniverse. p. 46. 2001. Print.

Stewart, Katherine A., and Madeline M. Maxwell. Storied Conflict Talk: Narrative Construction in Mediation. University of Texas at Austin: John Benjamins Publishing Company, 1984. Google book. Web. 20 Dec. 2018.

Warters, William C. Conflict Managemen in Higher Education Report. 2005.

Woehrle, Lynne M., and Kathryn Blakeman, eds. Journal for the Study of Peace and Conflict. Madison: The Wisconsin Institute. 2016. Print. 